\title{
Comparative study between immunoturbidimetric and latex agglutination methods for the detection of rheumatoid factor
}

\author{
Estudo comparativo entre as técnicas de aglutinação em látex e de \\ imunoturbidimetria para a detecção de fator reumatoide
}

Katya Cristina Rocha'; Luiz Alberto da Fonseca Brinque²; Claudia G. B. Oliveira³; Aleksandra Vanessa

Lambiasi Sant'Anna'; Alexandre Luiz Affonso Fonseca5; Ligia Ajaime Azzalis'; Edimar Cristiano Pereira’;

Virginia Berlanga Campos Junqueira ${ }^{8}$; Registila Libania Beltrame ${ }^{9}$; Fernando Luiz Affonso Fonseca ${ }^{10}$

\begin{abstract}
Introduction: The rheumatoid factor $(\mathrm{RF})$ is the most common antibody found in patients with rheumatoid arthritis. It is an inflammatory chronic disease characterized by articular involvement, inflammation of synovial fluid, tissue infiltration by leucocytes and joint destruction, which ultimately determine articular deformities. The rheumatoid factor is found in $70 \%-80 \%$ of the adult population and in $10 \%$ of the young population. Objective: The aim of this research was to compare immunoturbidimetric and latex agglutination methods for the detection of RF in serum. Results: The immunoturbidimetric method displayed sensitivity $(95.2 \%)$, specificity $(89.4 \%)$ and high positive correlation $\left(\mathrm{R}^{2}=0,8077\right)$ with the latex agglutination method in positive serum samples. Conclusion: The study allowed to demonstrate that both immunoturbidimetric and latex agglutination methods equally discriminate between negative and positive serum samples for RF.
\end{abstract}

Key words: rheumatoid factor; latex agglutination test; immunoturbidimetric method.

\section{INTRODUCTION}

As described by Waaler in 1937, patients with rheumatoid arthritis (RA) present auto-reactive antibodies against Fc fraction (fraction crystallizable) of immunoglobulin $\mathrm{G}$ (anti-IgC) in serum. Thereafter, such antibodies were denominated rheumatoid factor $(\mathrm{RF})^{(13)}$. The detection of $\mathrm{RF}$ in serum is not exclusively associated with RA cases, but it is also linked with other autoimmune diseases such as systemic erytematous lupus, Sjögren syndrome, bacterial infections and even healthy individuals ${ }^{(3,4)}$. In spite of the close association between the rise in $\mathrm{RF}$ and the triggering of inflammatory disease, the RF may also play a major physiological role in the regulation of autoimmune response as a whole: a) immune complex clearance: the RFs of immunoglobulin $\mathrm{G}(\mathrm{IgC})$ and immunoglobulin $\mathrm{M}$ (IgM) isotypes bind to immune complexes (complexes formed in the connection of antigens and their specific antibodies) in order to promote their opsonization, thus enabling complex removal by phagocytic cells ${ }^{(5,14)}$;

b) antigen processing and presentation by lymphocytes B (LB): the capture of RF by LB allows antigen internalization so that it may process these molecules and present them to lymphocytes $\mathrm{T}(\mathrm{LT})^{(5)}$;

c) activation of complement system by immune complexes, making them more soluble and, therefore, easily eliminated ${ }^{(14)}$.

Another major aspect that may be attributed to the natural formation of $\mathrm{RF}$ is the early establishment of antibody repertoire. Some antibodies may behave similarly to the RF. As far as physiology is concerned, the

First submission on 25/08/11; last submission on 12/12/12; accepted for publication on $05 / 01 / 13$; published on 20/02/13

1. Doctorate in Pathology (Immunology); assistant professor of Microbiology and Immunology at Faculdade de Medicina do ABC.

2. Specialist in Clinical Analysis; professor at Instituto Paulista de Ensino e Saúde de São Paulo (IPESSP).

3. Master's in Health Sciences by Faculdade de Medicina do ABC; clinical laboratory analyst.

4. Master's in Health Sciences by Faculdade de Medicina da Universidade de São Paulo (USP); clinical laboratory biologist.

5. Master's in Collective Health by Hospital Emílio Ribas; assistant professor at Universidade Paulista.

6. Doctorate in Biochemistry by Instituto de Química da USP; professor at the Department of Biological Sciences in the Universidade Federal de São Paulo (UNIFESP).

7. Doctorate in Clinical Analysis by Faculdade de Ciências Farmacêuticas da USP; associate professor at the Department of Biological Sciences in the UNIFESP.

8. Doctorate in Biochemistry; full professor at the Department of Biological Sciences in the UNIFESP.

9. Doctorate in Medical Education by Pontifícia Universidade Católica (PUC); professor of Immunology and Microbiology at Faculdade de Medicina do ABC.

10. Post-doctorate in Clinical Biochemistry; associate professor at the Department of Biological Sciences in the UNIFESP. 
formation of these antibodies may be connected with or even required for an early establishment of antibody repertoire able to bond with a wide range of ligands (with low binding affinity), thus enabling one more "barrier" to infection agents, particularly on mucosa ${ }^{(13)}$.

Despite the fact that RFs are found among healthy individuals and in patients with autoimmune diseases, mainly RA, the antibodies are distinctly different as to function. RFs detected in patients with RA have affinity maturation, whereas those detected in healthy individuals are multi-reactive, therefore they have low affinity. These considerations lead us to highlight the hypothesis that naturally formed RFs are under a rigid immunological control in order to prevent the appearance of high affinity antibodies, which have highly harmful potential ${ }^{(14)}$.

The RF test is frequently applied to differentiate RA from other forms of chronic arthritis. In RA cases, titers are generally higher in comparison with other related pathologies.

Nonetheless, the results should be judiciously interpreted due to the limited specificity of the method ( $80 \%$ sensitivity and $70 \%$ specificity on average) $)^{(21)}$. The surge in RF levels is directly connected with the presence of pathology and its prognosis, as it is corroborated in RA cases. Consequently, it is possible to notice extra-articular lesions as well as radiological erosions in RA patients with an increase in $\mathrm{RF}$ (IgM isotype above $50 \mathrm{UI} / \mathrm{ml})^{(10)}$.

From a clinical point of view, the serum detection of autoantibodies plays a pivotal role in the diagnosis and classification of the disease. Several technologies have been applied with the aim to identify autoantibodies (immunofluorescence, enzyme linked immunosorbent assay [ELISA], imunoblot and agglutination assay) and all of them have demonstrated high sensitivity and specificity. A growing number of major laboratories have applied turbidimetry and/or nephelometry for the detection of RF, mainly considering the advantage of automation and fast result release. The immune enzymatic assays are highly recommended when it is required to differentiate RF according to the antibody class: IgG, immunoglobulin class A (IgA) or IgM. Nonetheless, they are not widely available in routine laboratories ${ }^{(22)}$.

Considering the fact that some employed technologies pose some obstacles and technical limitations (some of them tend to be laborious, time consuming and semi-quantitative), the development of techniques that may be applied in an automated way could lead to a reduction in operational costs, minimization of technical errors and diminishment of reaction time. Hence, in order to obtain high performance assays in reduced time and with high reproducibility, it is appropriate to evaluate new technologies that aim at the quantification of autoantibodies such as $\mathrm{RF}^{(6)}$.

The present study had the objective to compare immunoturbidimetric and agglutination methods (latex method) for the determination of RF in serum.

\section{METHODS}

\section{Patients and samples}

We analyzed 304 samples from the Clinical Analysis Laboratory of Amparo-SP collected in 2007. Rheumatology outpatients from the Municipal Hospital were referred for RF analysis.
The samples were collected by venipuncture and distributed into $10 \mathrm{ml}$ tubes with negative pressure and without additive or anticoagulant. The serum samples were obtained after venous blood centrifugation at 2,500 rotations per minute (RPM) for 10 minutes. Lipemic and hemolyzed samples were discarded.

\section{Detection of RF by latex agglutination technique}

Artritest directo kit (Wiener Lab Rosário-Argentina) was applied for the detection of RF (IgM) by latex agglutination method. The semi-quantitative assay was performed in line with the manufacturer's technical recommendations. According to the manufacturer, the approximate concentration of $\mathrm{RF}$ in the sample may be calculated by the following formula: $\mathrm{RF}(\mathrm{UI} / \mathrm{ml})=$ titer $\times$ sensitivity reaction (1 UI/ml). The study revealed $88 \%$ sensitivity and $96 \%$ specificity.

\section{Detection of RF by immunoturbidimetric method}

Synchron CX 7-Delta Clinical System Beckman equipment (Beckman Coulter ${ }^{\circledR}$ Brea CA-USA) and Línea Turbitest AA kit (Wiener-Lab - Rosário - Argentina) were applied for the detection of RF by immunoturbidimetry (autoantibodies for RF - $\operatorname{IgM} / \operatorname{IgG}$ ). The manufacturer's technical recommendations were followed. The values considered negative ranged from 0 to $20 \mathrm{UI} / \mathrm{ml}$.

\section{Statistical analysis}

Initially, all variables were analyzed descriptively. The analysis of quantitative variables comprised minimum and maximum values, mean values, standard deviation and media. The absolute and relative frequencies were calculated for the qualitative variables. The association of latex agglutination and turbidimetric methods were performed through non-parametric Mann-Whitney test, inasmuch as normality of gathered data was rejected. The correlation analysis between turbidimetric and latex agglutination methods was assessed through Spearman coefficient.

\section{RESULTS}

\section{Characterization of the studied population}

We collected samples from 304 patients with age range from 8 to 88 years (mean age $48.06 \pm 17.13$ years). 229 (75.3\%) were female and 75 (24.7\%) were male. Lipemic, icteric or hemolyzed samples were excluded, determining a total of 272 analyzed samples.

\section{Detection of RF by latex agglutination method}

272 samples were analyzed from a total of 304 , from which $8.82 \%$ ( 24 samples) were considered positive (latex reagent) after the appliance of semi-quantitative test. The titers varied from 2.048 (maximum value) to 0 (minimum value), mean value 14.74 and standard deviation $\pm 132.5 .25 \%$ of the positive samples were from the male group and $75 \%$ from the female group. 


\section{Detection of RF by immunoturbidimetric method}

272 samples were analyzed from a total of 304 , from which 9.55\% (26 samples) were positive, considering the fact that $23.07 \%$ were from the male group and $76.93 \%$ were from the female group. The titer varied from 881 (maximum value) to 2.5 (minimum value), mean value 22.26 and standard deviation \pm 72 . It is particularly worth mentioning that all samples considered positive by the latex agglutination method were also confirmed positive by immunoturbidimetry (Figure). Only two samples were not considered positive by both methods (positive by immunoturbidimetry and negative by latex agglutination), as it is shown in the Table.

Despite the fact that we identified two discordant samples (positive by immunoturbidimetry and negative by latex agglutination), the determination of Spearman coefficient allowed the identification of strong positive correlation between both methods $\left(\mathrm{R}^{2}=0.807\right)$ (Figure).

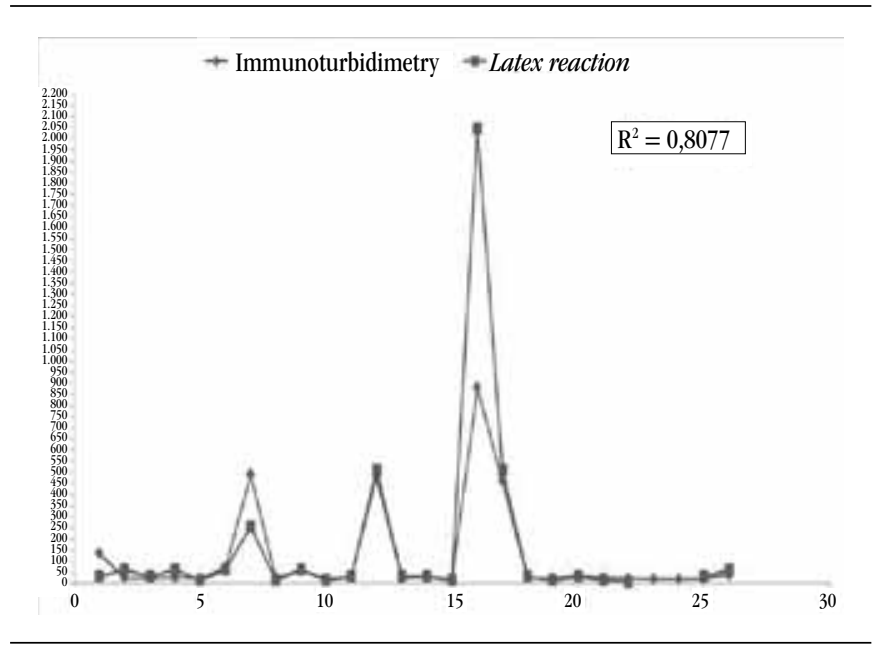

$\overline{\text { FIGURE - Dosages of positive RF quantified by immunoturbidimetry (UI/ml) and by latex }}$ agglutination method (UI/ $\mathrm{ml})$

$R^{2}$ represents the correlation between both methods through the determination of Spearman coefficient.

TABELA - Positive values for immunoturbidimetry and latex reaction

\begin{tabular}{llll}
\hline $\mathrm{R}$ & 136 & $\mathrm{R}$ & 32 \\
$\mathrm{R}$ & 25.8 & $\mathrm{R}$ & 64 \\
$\mathrm{R}$ & 25.3 & $\mathrm{R}$ & 32 \\
$\mathrm{R}$ & 27.6 & $\mathrm{R}$ & 64 \\
$\mathrm{R}$ & 24.1 & $\mathrm{R}$ & 16 \\
$\mathrm{R}$ & 69.7 & $\mathrm{R}$ & 64 \\
$\mathrm{R}$ & 490 & $\mathrm{R}$ & 256 \\
$\mathrm{R}$ & $\mathrm{R}$ & 16 \\
$\mathrm{R}$ & 23.2 & $\mathrm{R}$ & 64 \\
$\mathrm{R}$ & 59.6 & $\mathrm{R}$ & 16 \\
$\mathrm{R}$ & 20.3 & $\mathrm{R}$ & 32 \\
$\mathrm{R}$ & 30.1 & $\mathrm{R}$ & 512 \\
$\mathrm{R}$ & 478.2 & $\mathrm{R}$ & 32 \\
$\mathrm{R}$ & 24.3 & $\mathrm{R}$ & 16 \\
$\mathrm{R}$ & 29.9 & $\mathrm{R}$ & 2.048 \\
$\mathrm{R}$ & 22.0 & $\mathrm{R}$ & 512 \\
$\mathrm{R}$ & 881 & $\mathrm{R}$ & 32 \\
$\mathrm{R}$ & 462 & $\mathrm{R}$ & 16 \\
$\mathrm{R}$ & 26.3 & $\mathrm{R}$ & 32 \\
$\mathrm{R}$ & 23.8 & $\mathrm{R}$ & 16 \\
$\mathrm{R}$ & 34.2 & $\mathrm{R}$ & 8 \\
$\mathrm{R}$ & 26.5 & $\mathrm{R}$ & - \\
$\mathrm{R}$ & 24.4 & $\mathrm{NR}$ & 32 \\
$\mathrm{R}$ & 20.2 & $\mathrm{~N}$ & 64 \\
$\mathrm{R}$ & 20.3 & $\mathrm{R}$ & - \\
$\mathrm{R}$ & 22.0 & $\mathrm{R}$ & $\mathrm{R}$ \\
\hline
\end{tabular}

The calculation for yielding $R F$ values $(U I / m l)$ was performed in accordance with information supplied by the manufacturer: $R F(U I / m l)=$ titer $\times$ reaction sensitivity ( $1 \mathrm{UI} / \mathrm{ml})$.

$R$ : reagent; $N R$ : non-reagent; $R F$ : rheumatoid factor: 


\section{DISCUSSION}

It is widely known that the RF is not exclusively produced under pathological conditions and a small percentage of the normal population, mainly elderly individuals, may be positive. The prevalence of both among diseased and healthy individuals varies according to the sensitivity and specificity of the method employed $^{(1)}$. As to comparative studies of RF detection methods and RA diagnosis, the literature data are still very limited.

According to the agreement for the diagnosis and initial evaluation of RA presented by Sociedade Brasileira de Reumatologia $2011^{(9)}$, the disease should not be diagnosed through the performance of one solely laboratory method. According to the authors, the detection of RF and the quantification of anti citrulline antibodies would be regarded as only prognostic markers. In isolation, the diagnostic value of RF is limited, insofar as 30\% to $50 \%$ of patients may be seronegative for this autoantibody initially ${ }^{(11)}$. The RF may also be positive for patients without arthritis, and its positivity may be higher among elderly individuals ${ }^{(15)}$. It may be present in several other rheumatologic conditions or not. Thus, the negativity for RF does not exclude the diagnosis of RA and its positivity should be thoroughly interpreted according to clinical findings. Brazilian data (incidence cohort of initial RA) show RF prevalence in approximately $50 \%$ of patients ${ }^{(8,15,17)}$

According to investigation carried out by Mota et al. ${ }^{(9)}$, the detection of isotype IgM may be regarded as a useful marker in order to distinguish patients with poli arthritis that progressed to characteristic RA clinical status. Approximately $50 \%$ of these patients may present positivity to RA IgM, whereas the detection of other isotypes is still highly disputable $(7,9,12,16,17)$.

Regardless of the method employed herein for the detection of RF, most seropositive patients were female (76.93\% positivity by immunoturbidimetry and $75 \%$ by latex agglutination method). The cause is still unknown, but there is strong evidence that hormones may play a crucial role in the development of the disease ${ }^{(2)}$.

A case-control study was carried out in Sweden and the researchers pointed out some characteristics that may increase or decrease the risk of RA in women who were positive for $\mathrm{RF}$ and anti citrulline antibodies. According to these authors, the hormonal influence is clearly evinced, inasmuch as women who breastfed for a longer period had a higher risk for the development of the disease, whereas women in use of oral contraceptive ( $>7$ years) had a reduction in the risk of developing $\mathrm{RA}^{(2)}$. In our investigation, female patients that were positive for RF were on average 54.6 years old (39-77 years), most of them in their menopause (> 50\%).

The correlation analysis between both techniques demonstrated high positive correlation $\left(\mathrm{R}^{2}=0.8077\right)$. Therefore, in both techniques (both from the same manufacturer) it was possible to observe positivity and increase in detected levels when the samples were positive. Only two were discordant $(0.73 \%)$ in a total of 272 studied samples. Similarly, evaluating patients with RA and other rheumatologic diseases and using nephelometry and sensitized gelatin particle agglutination, Spiritus et al. ${ }^{(18)}$ demonstrated that the latter showed better diagnostic performance in comparison with nephelometry. Nevertheless, the authors showed that the combination of both techniques may significantly optimize the detection of RF in comparison with their isolated use. As far as our investigation is concerned, it is important to highlight that the high correlation may be the result or even may be associated with the fact that different techniques were applied, though the commercial kits were from the same manufacturer. Hence, it is particularly worth mentioning that if the same techniques are used with commercial kits from different manufacturers (other than Laboratory Wiener), the yielded results should not be extrapolated and new validation is required.

Visser et al. ${ }^{(19)}$ clearly showed that ELISA test may be considered a reasonable substitute test to the agglutination assay for the detection of RF (IgM) in patients with RA, emphasizing the pivotal role played by agglutination tests as well as their diagnostic performance ${ }^{(19)}$. Saraux et al. ${ }^{(20)}$, after assessing three different methods (latex particle agglutination, ELISA-RF IgM and IgG anti-keratin) for the diagnosis of RA, concluded that all of them presented excellent discrimination in the diagnosis of this arthropathy, which evinces the potential of the agglutination test for RF dosing ${ }^{(20)}$.

The study of these distinct methods, though with the same goal in clinical analysis laboratories, shows advantages and disadvantages for each method, apart from data such as sensitivity, specificity and cost-effectiveness, which allow the optimization of yielded results. It is worth noting that for the performance of immunoturbidimetry a new calibration curve is required for each change in reagents, whereas for the performance of slide reaction methods with latex particles only a control positive or negative is required. As to cost-effectives, agglutination assays are more affordable than turbidimetry. For example, a kit for slide agglutination is estimated at $\mathrm{R} \$ 76,80$ and performs 50 tests. Each test, therefore, is carried out at the cost of $R \$ 1,53$. Whereas the immunoturbidimetric (turbitest) is estimated at $\mathrm{R} \$ 195,00$ with total performance of 100 tests and the cost of each test is $R \$ 1,95$.

Consequently, in face of the yielded results we may infer that the latex agglutination method for the detection of $\mathrm{RF}$ is as efficient as immunoturbidimetry. On the other hand, the latter is cost-effective, it does not require exceeding materials and it is rapidly carried out. The choice of immunoturbidimetry or agglutination test should take into consideration the laboratory demand (available technical team, number of exams and target audience). 


\section{RESUMO}

Introdução: O fator reumatoide (FR) é o autoanticorpo mais comum encontrado em pacientes com artrite reumatoide, uma doença crônica inflamatória caracterizada pelo envolvimento articular com inflamação do híquido sinovial, infiltração de tecido por leucócitos e destruição das articulações, que acaba por determinar deformidades articulares. O FR é encontrado em 70\%-80\% da população adulta e em 10\% da população juvenil. Objetivo: Comparar os métodos de imunoturbidimetria e aglutinação (prova do látex) para a determinação de FR em soro. Resultado: Foi possivel observar que o método imunoturbidimétrico apresenta sensibilidade (95,2\%), especificidade $(89,4 \%)$ e correlação positiva elevada $\left(R^{2}=0,8077\right)$ com o método de aglutinação pelo látex em amostras de soro positivas. Conclusão: 0 estudo permitiu demonstrar que o método imunoturbidimétrico e o método de aglutinação pelo látex são igualmente capazes de discriminar amostras negativas e positivas para FR.

Unitermos: fator reumatoide; método de aglutinação do látex; método imunoturbidimetria.

\section{REFERENCES}

1. BALASSIANO, E.; DANTAS, F. E.; ROCHA, G. L. Estudos sorológicos do psoríase. Anais Brasileiros de Dermatologia, v. 56, n. 1, 1981.

2. BERGLIN, E.; KOKKONEN, H.; EINARSDOTTIR, E.; ÅGREN, A.; DAHLQVIST, S. R. Influence of female hormonal factors, in relation to autoantibodies and genetic markers, on the development of rheumatoid arthritis in northern Sweden: a case-control study. Scand J of Rheumatol, v. 39, n. 6, p. 454-60, 2010 .

3. BETTERO, R. G.; CEBRIAN, R. F. M.; SKARE, T. L. Prevalência de manifestações oculares em 198 pacientes com artrite reumatoide: um estudo retrospectivo. Arq Bras Oftalmol, v. 71, n. 3, p. 365-9, 2008.

4. CARSON, D. A. et al. Rheumatoid factor and immune networks. Ann Rev Immunol, v. 5, p. 109-26, 1987.

5. CARSON, D. A.; CHEN, P. P.; KIPPS, T. J. New roles for rheumatoid factor. J Clin Invest, v. 87, p. 379-83, 1991.

6. LLEO, A.; INVERNIZZI, P.; GAO, B.; PODDA, M.; GERSHWIN, M. E. Definition of human autoimmunity - autoantibodies versus autoimmune disease. Autoimmunity Reviews, v. 9, n. 5, p. A259-66, 2010.

7. MOTA, L. M. H.; NETO, L. L. S.; BURLINGAME, R.; LAURINDO, I. M. M. Comportamento distinto dos sorotipos do fator reumatoide em avaliação seriada de pacientes com artrite reumatoide inicial. Rev Bras Reumatol, v. 49, n. 3, p. 223-35, 2009.

8. MOTA, L. M.; dos SANTOS NETO, L. L.; BURLINGAME, R.; MÉNARD, H. A.; LAURINDO, I. M. Laboratory characteristics of a cohort of patients with early rheumatoid arthritis. Rev Bras Reumatol, v. 50, n. 4, p. 375-88, 2010.

9. MOTA, L. M. H. et al. Consenso da Sociedade Brasileira de Reumatologia 2011 para o diagnóstico avaliação inicial da artrite reumatoide. Rev Bras Reumatol, v. 51, n. 3, p. 199-219, 2011.

10. NELL, V. P. et al. Autoantibody profiling as early diagnostic and prognostic tool for rheumatoid arthritis. Ann Rheum Dis, n. 64, p. 1731-6, 2005.

11. RENAUDINEAU, Y.; JAMIN, C.; SARAUX, A.; YOUINOU, P. Rheumatoid factor on a daily basis. Autoimmunity, v. 38, p. 6-11, 2005.
12. SARAUX, A. et al. Value of laboratory tests in early prediction of rheumatoid arthritis. Arthritis Rheum, v. 47, p. 155-65, 2002.

13. SOLTYS, A. J.; AXFORD, J. S.; SUTTON, B. J. Rheumatoid factors: where are we now? Annals of the Rheumatic Diseases, v. 56, p. 281-6, 1997.

14. SONG, Y. W.; KANG, E. H. Autoantibodies in rheumatoid arthritis: rheumatoid factors and anticitrullinated protein antibodies. Q J Med, v. 103, p. 139-46, 2010.

15. VISSER, H.; GELINCK, L. B.; KAMPFRAATH, A. H.; BREEDVELD, F. C.; HAZES, J. M. Diagnostic and prognostic characteristics of the enzyme linked immunosorbent rheumatoid factor assays in rheumatoid arthritis. Ann Rheum Dis, v. 55, p. 157-61, 1996.

16. VITTECOQ, 0. et al. Rheumatoid factor is the strongest predictor of radiological progression of rheumatoid arthritis in a three-year prospective study in community-recruited patients. Rheumatology, v. 42, p. 939-46, 2003. 17. WOLFE, F; CATHEY, M. A.; ROBERTS, F. K. The latex test revised rheumatoid factor testing in 8,287 rheumatic disease patients. Arthritis Rheum, v. 34 , p. $951-60,1991$.

18. SPIRITUS, T.; VERSCHUEREN, P.; WESTHOVENS, R.; BOSSUYT, X. Diagnostic characteristics of a gelatin based Waaler-Rose assay (Serodia-RA) for the detection of rheumatoid factor. Ann Rheum Dis, v. 63, p. 1169-71, 2004 .

19. VISSER, H.; GELINCK, L. B. S.; KAMPFRAATH, A. H.; BREEDVELD, F. C.; HAZES, J. M. W. Diagnostic and prognostic characteristics of the enzyme linked immunosorbent rheumatoid factor assays in rheumatoid arthritis. Annals of the Rheumatic Diseases, v. 55, p. 157-61, 1996.

20. SARAUX, A. et al. Value of laboratory tests in early prediction of rheumatoid arthritis. Arthritis Rheum, v. 47, n. 2, p. 155-65, 2002.

21. HELLMANN, D. B.; STONE, J. H. Arthritis \& musculoskeletal disorders. In: TIERNEY, L. M. et al. Curr Med Diag Treat. 43. ed. New York: McGraw-Hill, 2004. p. 797-825.

22. HABASH-BSEISO, D. E. et al. Serologic testing in connective tissue diseases. Clin Med Res, v. 3, n. 3, p. 190-3, 2005.

\section{MAILING ADDRESS}

